\title{
Realia as Carriers of National and Historical Overtones
}

\author{
Ketevan Djachy \\ Romance Department, College of Arts and Sciences, Ilia State University, Georgia \\ Mariam Pareshishvili \\ U University of Patriarchate of Georgia, Georgia
}

\begin{abstract}
This article considers the strategies of translating realia. In the theory of translation, realia are words and phrases that designate objects and concepts closely linked with a particular national culture. Realia are frequently used in the products of the mass media. The main features of realia are their national and historical overtones. The task of the translator is to maintain these national and historical overtones in the target text. The translator must analyze the culture-specific elements of realia in the source text and re-define their place in the target context.
\end{abstract}

Index Terms - realia, traductology, headlines, background information, nonequivalent vocabulary, translator, methods of translation

\section{INTRODUCTION}

According to L. Barkhudarov (1975) the system of linguistic meanings, in any language, represents the outer as well as inner world of a person, i.e. encompasses practical experience of a group of people speaking the same particular language. If the practical experience of groups of people speaking different languages is the same, so are the notions expressed in these languages. The main challenge that a translator faces in the process of translation is when a reference in the source language is made to a situation absent in the experience of the group of people speaking the target language, i.e., when the source language contains so called realia (Barkhudarov, 1975, p. 94).

The notion of realia, in its modern sense, did not exist in times of Vinay, J. P. and Darbelnet J. In the theory that dates back to 1958, they speak of "the differences of metalinguistic character" and describe them as follows: "they represent a combination of the relations connecting social, cultural and psychological phenomena to linguistic structures". According to them, these "cultural and metalinguistic differences" enclose craft, measuring units, social life, schools and universities background information (Vinay, J. P. \& Darbelnet J. 1958, p. 259).

According to the definition offered by L. Barkhudarov (1975), realia represent a part of background information, implying specific historic facts and information about the state structure, the peculiarities of the geographic environment, concepts of ethnography and folklore. In the theory of translation, the words or expressions denoting the objects of material culture and closely connected to a particular nation's culture are called realia. The peculiarities connected with the translation of these elements must be taken into consideration in the process of translation (Barkhudarov 1975, p. 94).

\section{Methodology}

Our paper combines interdisciplinary and comparative methodologies that will enable to show the essence of the realia. The interpretative approach to text analysis implies interaction between the text and its reader. This kind of analysis emphasizes the mental activities of the reader who is engaged in building the world of the text, which is based on his/her background knowledge of the world in general.

\section{RESULTS AND ANALYSIS}

Realia are very common in mass media; therefore knowledge and awareness of socio-political realia is indispensible for a translator of these kinds of texts (these are concepts related to administrative-territorial arrangement of a country). This kind of realia are translated by means of transcription/transliteration, as well as by means of descriptive translation

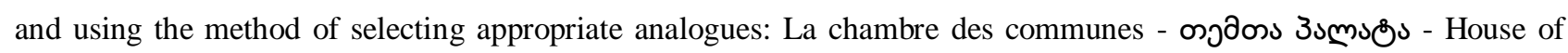

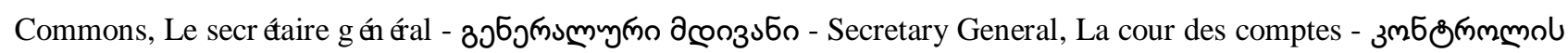
3ımsos - The Chamber of Control.

Realia represent the symbols carrying the overtones of national and historic distinctiveness. Rendering this very distinctiveness is the most challenging task performed by a translator. Since any element of realia is a part of the main 
text, appropriate interpretation of these realia into the relevant target language is one of the prerequisites of adequate translation. For example:

- François Bayrou nomme un "shadow cabinet" (Le Point 21/09/2010) / François Bayrou forms a "shadow cabinet"/

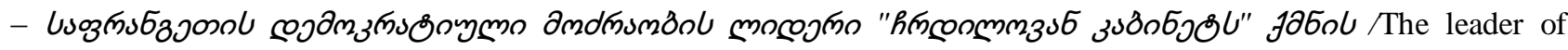

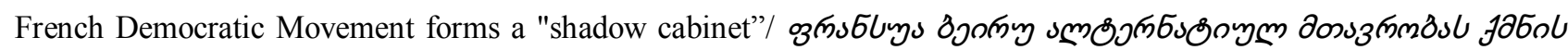
/François Bayrou will launch an alternative government/;

- Bartolone: "pas question que l'Assemblée recule" sur le mariage homosexuel (Le Point 02/12/2012) /Bartolone:

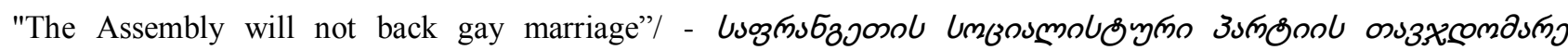

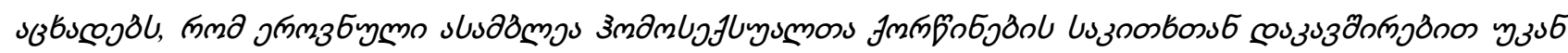

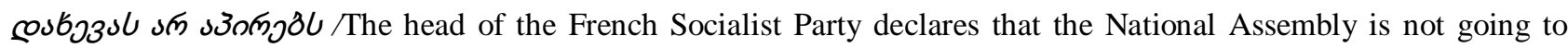
compromise on the issue of gay marriage/.

Both titles contain political realia; British element of realia "shadow cabinet" is used in the first example, an analogue of which does not exist in the French political reality. Accordingly, the French journalist tries to preserve the peculiarity of this element of realia expressing it by means of transcription in the title of the French article. We think the Georgian reader needs some explanation of this element of realia. "Shadow Cabinet" means an alternative government, which, as a rule, is formed by the leaders of the opposition political forces and the aim of forming it is to control the government. The members of a shadow cabinet shadow or mark each individual member of the government. The idea is that shadow cabinet becomes a legitimate government if and when their party gets into government. We present two versions of translation of the title: in the first case, we try to preserve the peculiarity of the given element of realia, as long as it is present in the French title; in the second case, the generalization of the element of realia is given in the form of "alternative government". In this particular case, we prefer the second translation of the title, offering full information disclosure to the reader, even at the expense of overshadowing the overtones of the element of realia. Besides, we define who "François Bayrou" is. In the first version of the Georgian translation of the title, unlike the French title, his name is not mentioned, instead a reference is made to his position. In the second example, French element of realia "L'Assemblée" is used, which, without any further explanation, is absolutely understandable for French readers, but not for the majority of Georgian readers. The French element of realia given in the title refers to the French "National Assembly", i.e., lower house of the Parliament of France, which is expected to discuss the issue of gay marriage. Instead of the name of the person (Bartolone) the translation uses the position held by the person, as it was done in the case of the first example, making the task of understanding the text easier for Georgian readers.

It is the translator who decides on the strategy of translating realia. A single element of realia can be translated in two or three different ways and all of the translations can be correct, if they accurately convey the meaning of the word or the word-combination.

Some scholars determine realia to be a particular category of "nonequivalent expressive vocabulary". V. Kostomarov and E. Vereshagin (1990) define "nonequivalent vocabulary" as follows: "these words and word-combinations are used to denote the notions of a nation which are unfamiliar to another one. they are associated with specific cultural elements existing within a particular culture but those that cannot be found in another; They also include the words that cannot be translated into a target language using one single word, that have no equivalents in another language" (Kostomarov \& Vereshagin, 1990, p. 53).

According to L. Barkhudarov (1975) "nonequivalent vocabulary" mainly includes the following groups of words:

1. Words that denote the objects, concepts and situations nonexistent in the practical experience of the groups of people speaking other languages.

2. Words that denote the objects characteristic of the material and spiritual culture of a particular nation. For example, national dishes, clothes, shoes, etc.

3. Words and set expressions, denoting the political institutions and social events characteristic of a particular nation (Barkhudarov, 1975, p. 93).

It should be noted that the term - "nonequivalent vocabulary" - is used only in the sense that no equivalent of a given lexical unit exists in the vocabulary of the other language, though V. Kostomarov and E.Vereshagin consider that it does not mean that they cannot be translated, because any concept or notion can be expressed in virtually any language (Kostomarov \& Vereshagin, 1990, p. 53).

However, L. Barkhudarov (1975) believes that it is not always easy to determine in which cases a word can be considered as belonging to "nonequivalent vocabulary", because some products of translation referred to as occasional equivalents can be formed as set expressions (Barkhudarov, 1975, p. 95).

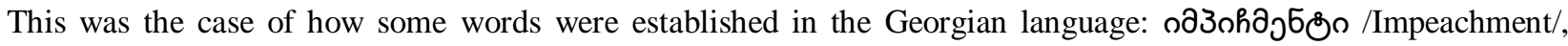

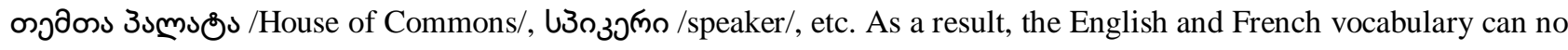
longer be considered as "Nonequivalent vocabulary". For example: 


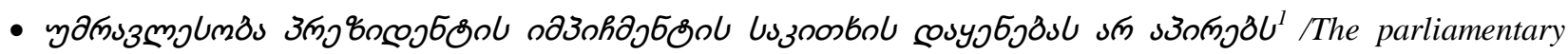
majority do not intend to raise the issue of the impeachment of the president/ - Géorgie: la majorite parlementaire n'envisage pas d'engager une procédure de mise en accusation du Président de la République /Georgia: parliamentary majority do not intend to initiate the indictment against the President of the Republic/; La majorite parlementaire n'entend pas déclencher la procédure d'impeachment du Président Saakashvili /The parliamentary majority do not intend to initiate the impeachment of President Saakashvili/.

We present two versions of the translation of the title. The word "impeachment" belongs to "nonequivalent vocabulary", which was originally calqued into the Georgian Language. Impeachment is a formal procedure implied in a constitutional law and envisaging legal proceedings against a high official accused of unlawful activity. The calque of the word is not widely used in the French language and is generally expressed as "la mise en accusation"/'indictment"/, though in some cases it is calqued (la procédure d'impeachment/impeachment/).

In L. Barkhudarov's opinion (1975) the absence of special meaning in the form of a word or a set expression in the vocabulary of a particular language does not mean that it is impossible to express the concept by linguistic means of the language. Even though a concept might be missing in the particular language system, it is always possible to convey the meaning of the contents using a range of means (Barkhudarov, 1975, p. 96).

\section{Discussions AND CONCLUSIONS}

According to G. Tomakhin (1997), before starting translation, it is necessary to gain awareness of an unknown element of realia included in the source text, we must determine its place in the given context, how the author tries to convey it and what methods he uses to make the semantic content and connotative meaning of the given element of realia understandable for the reader. Most often it is foreign realia describing the reality unfamiliar to the target language that need to be processed thoroughly as it is described above. As for the national realia, they do not require any kind of processing, for example, "hy๓nhbjms"/"churchkhela", for the Georgian reader does not require any explanation, as well as "mistral" - for the French reader and "Tower" - for the English reader. International realia, on the other hand, do not require as much effort to make them understandable as national realia do, because due to the range of their dissemination, the reader is supposed to have a certain idea of the realia and their national origin (Tomakhin, 1997, p. 17).

S. Vlahov and S. Florin (1986) consider that two major difficulties arise in the course of translation of realia. These are: 1. lexical vacuum, i.e., absence of the equivalent or analogue in the target language, due to the fact that there is no object (referent) denoted by the given element of realia in the reality of the reader of the target language and 2. the necessity to render the overtones of the element of realia along with its semantic meaning (Vlahov \& Florin 1986, p. 89).

In V. Komisarov's opinion (1990) some of the realia have a single equivalent in the given target language, for

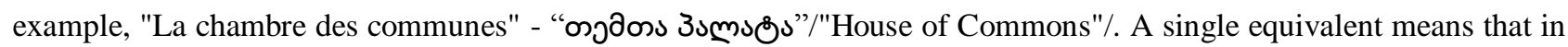
most cases the lexical unit given in the source text is translated as one and the same lexical unit into the target language, i.e., the difficulties of translating such an element of realia does not actually arise (Komisarov, 1990, p. 175).

There are several ways of translating realia. L. Barkhudarov (1975) suggests following methods of translating realia: transliteration/transcription, coining a new word, approximate translation, hyponymic translation, calquing, creating a semantic neologisms, replacement of the given realia and periphrastic translation.

The methods used in the process of translating the newspaper articles concerning politics, are generally confined to transcription, transliteration, calque, semi-calque, approximate translation, hyponymic translation and contextual translation. Other methods are rarely used in terms of translating political realia.

1. Transcription and transliteration mean introduction of a given element of realia into a text using graphic units of the target language through achieving maximum possible resemblance of the phonetic means of the target language to that of the source language. In case of transliteration, a word used in the source text is introduced into the target language via graphic form of the target language, whereas in case of transcription, sound form of a given word is taken

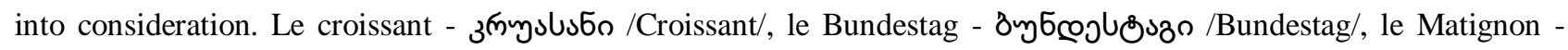

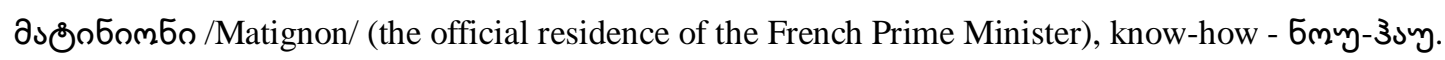

- Le Bundestag se prononce à nouveau sur l'aide à la Grèce ${ }^{2} /$ Bundestag repeatedly launched the issue of providing

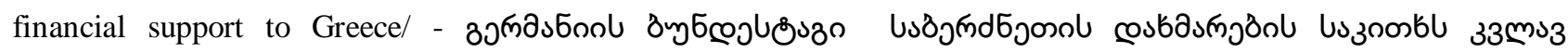

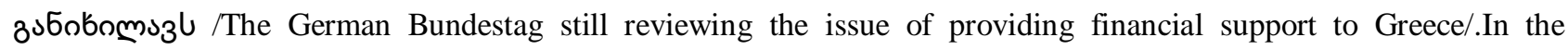
translation of the title given above, the element of German political realia "Bundestag" is given in the form of transcription but the word "German" is added, so that the reader has no difficulties in perception of the situation.

\footnotetext{
${ }^{1}$ http://news.ge/ge/news/story/37440

${ }^{2}$ http://eventsmonde.com
} 
In case of a successful transcription, the translator manages to express both the content and the overtones of the given element of realia. In case the target language lacks the sound, which sounds similar to that used in the element of realia of the source language, combination of letters is used to achieve the resemblance to the corresponding sound. Translators tend to use transcription quite often; however, the use of this method depends on the recipient of the target text. The translator should take into consideration the extent of spread of the given element of realia and whether it is known to the target reader, not to throw the reader into confusion. For example, when the words "Znsmo" /PR"/ or

"mmరింபீింరిం"/"lobbyists"/ are used, the concepts are generally understandable for young readers and cause almost no misunderstanding, however, if these concepts are used in the magazines or newspapers, the readers of which might be elderly people, the translator has to think about whether it is relevant to use the transcription of these concepts and

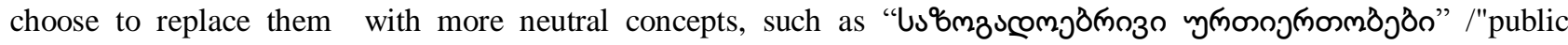

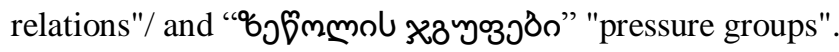

2. Calque and calquing - allows introduction of a given element of realia into the target language through preserving its semantics as much as possible. However, preservation of the semantics of an element of realia does not mean preservation of its distinctiveness and overtones as the process involves expression of a part of the word by means of

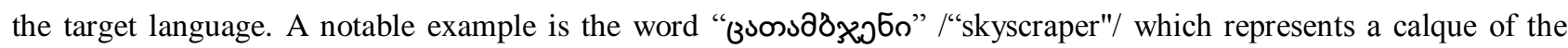
English word "skyscraper" (French: le gratte-ciel). The method of calquing is common in translating proverbs when, for different reasons, it is necessary to preserve not only their ideas, but also their semantic grounds. For example: Une

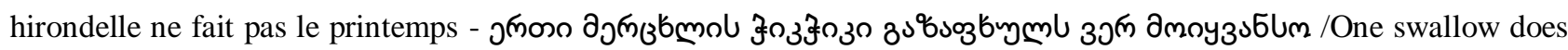
not make a spring/.

3. Semi-calque - represents a method allowing borrowing of a part of word when the word consists of elements of

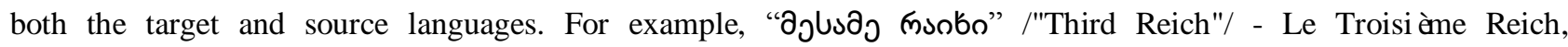

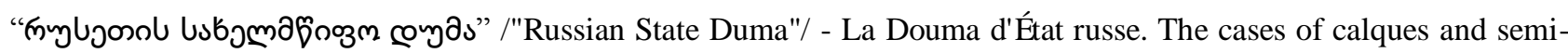
calques finding a firm ground and spreading in a given language is quite frequent but they still remain as "exotic word" as their denotations remain unfamiliar to the readers of the target language texts.

4. Hyponymic translation - this method of translating realia involves replacement of a concrete concept by a general concept in the process of translating realia and is mainly used in cases when a translator's task is to render an unknown, unfamiliar element of realia to the target reader. The basis of the hyponymic translation is the method of generalization. The element of realia is expressed by a linguistic unit having a broader meaning. The method of generalization is a widely used method, which is used to avoid the application of the method of transcription and makes it possible to replace an element of realia by a concept that does not make a big difference in the given context. For example:

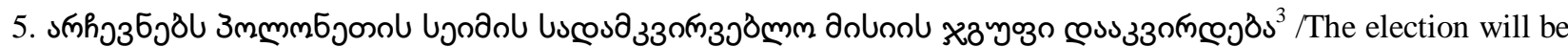
overseen by a group of the monitoring mission of the Sejm of the Republic of Poland/ - Le Parlement polonais va envoyer une mission d'observation électorale en Géorgie /The Polish parliament will send an electionl observation mission to Georgia

The method used in the translation of the element of Polish realia included in the given title is hyponymic translation.

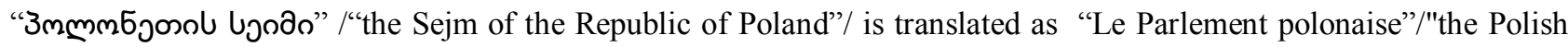
parliament"/, thus making the understanding of the title easier for the French reader.

6. Approximate translation - is the widely spread method. Using the functional equivalent of an element of realia, causing the same association in the reader as the original text, is quite common. The method is based on selection of a

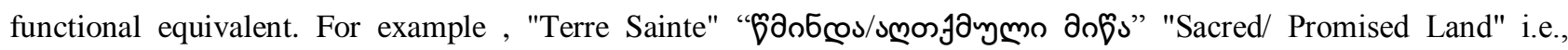

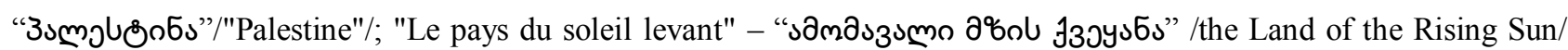
i.e. "os3m6ns"/"Japan"/.

7. Contextual translation - the method is essentially similar to the approximate translation and is inconsistent with the method of translation based on the usage of a dictionary, since the translation of a word, using this method, results in a word that does not match the equivalents of the word of the source language given in any dictionary. In this case, the translator is focused on the context. This method itself implies replacement of a translation of the word given in a dictionary with a contextual, logically related word. The shortcoming of such a translation is that it completely neglects the element of realia as national overtones and distinctiveness (Barkhudarov 1975, p. 96).

- Angela Merkel, la «Tsarine» de la droite allemande/ Angela Merkel, the "Tsarina" of the German right-wing party/

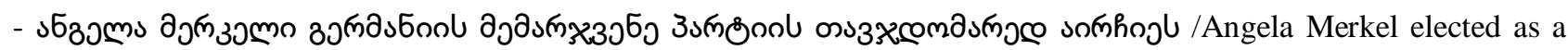
chairperson of the German right-wing party/.

\footnotetext{
${ }^{3}$ http://www.internet.ge/?1=GE\&m=1 \&sm=0\&ID=12064
} 
In the translation of the title given above, the Russian realia "Tsarina" is replaced by a contextual equivalent

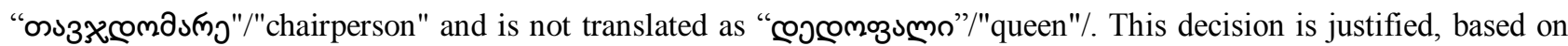
the content of the article.

It should be noted that one of the most common ways of translating realia is transcription. Transcription is widely used in translating common, international and local realia. The advantage of transcription is the maximum laconism that is characteristic of transcription. The product of transcription is, as a rule, followed by a footnote or explanation. Though, experienced translators and theorists often recommend being selective and moderate in using foreign-language words, since, in some cases, rendering the overtones is not the determining factor and risk obscuring semantic meaning of a given element of realia, thus failing to fulfill the communicative function of translation ${ }^{4}$. For example:

- Fukushima: "le gouvernement refuse d'admettre la gravité de la situation" "Fukushima: the government refuses to

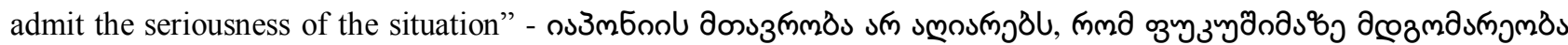

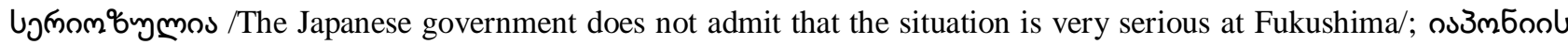

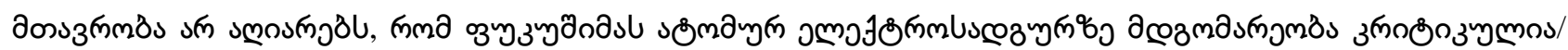
The Japanese government does not admit that the situation is critical at the Fukushima nuclear power plant/.

- Un membre palestinien de la Knesset israélienne dénonce la Résolution 1701 des Nations Unies ${ }^{6} / A$ Palestinian

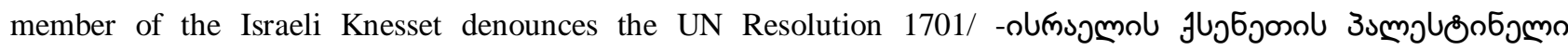

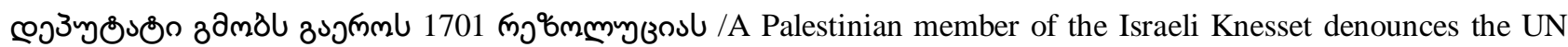

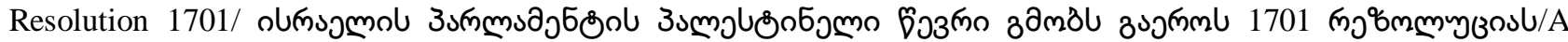
Palestinian member of the Israeli parliament denounces the UN Resolution 1701/.

In the translation of the titles given above, the realia are given in the form of transcription. We offer two versions of translation in case of each title; notwithstanding the fact that both elements of realia are more or less well known to the target reader, we think, the second versions of the translation, in which lexical additions are used, convey the essence of the titles with more accuracy.

The use of the method of transliteration in translation of realia is less frequent. Transliteration can only be used in the translation of the concepts that have to deal with social-political life or of proper nouns ${ }^{7}$.

However, due to the similarity between the methods of transcription and transliteration, it is very difficult to distinguish them from each other. We should remember that excessive use of transcribed words denoting realia in the target text does not contribute to the preservation of national overtones, but, on the contrary, destroys them and makes the reader stumble upon redundant exotic words at every single step ${ }^{8}$. The use of foreign words in the text is justified only in case when an equivalent of a particular element of realia is absent is the target language.

L. Barkhudarov (1975) believes that, despite the difficulties, translation of realia is possible [...]. Any language holds the possibility of describing a new situation and this possibility is an integral part of any language. It is this very feature of a language that makes it possible to describe the specificities of the life of a nation, which have no analogue in the reality of other countries and nations, by means of the language of another nation (Barkhudarov, 1975, p. 98).

In our era of globalization, sometimes realia of one nation are easily transferred in another nation, for example, a lot of political realities were nonexistent in our country, such as Prime Minister, the Ombudsman, the House of Justice , NGOs, etc. that, nowadays, have found a firm ground in Georgian reality and are well-established in our country. Though, it should be also noted that some of the elements of the Soviet realia are established in the French language and they serve the purpose of expressing the realia that stand for the realities of the former republics of the Soviet Union. For example:

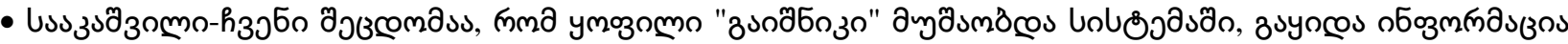
ç $3>0 f(3\lrcorner^{9} /$ Saakashvili - It is our fault that the former "GAI inspector" was employed by the system, he sold the information and ran/ - SaakaShvili: c'est notre erreur d'avoir recruté un ancien gaïchnik dans le système pénitentiaire du pays, qui avait empoché de l'argent en vendant des vidéos des abus de la prison et s'était enfui / Saakashvili: it is our mistake to have hired a former Gaichnik in the prison system of the country, who had pocketed the money by selling videos of the prisoner abuse and ran/.

In the process of translation of the title given above, it becomes necessary to use lexical addition to provide the French readers with the detailed information about the content of the article. The title specifies that the matter concerns the footage depicting facts of prison torture in the prisons of Georgia that is not indicated in the Georgian title. As for

\footnotetext{
${ }^{4}$ http://referat.ru/referats/view/23656

${ }^{5} \mathrm{http}: / /$ www.humanite.fr/monde/477656

${ }^{6} \mathrm{http}: / /$ fr.dir.groups.yahoo.com/group/islam_jeunesse_international/message/16964

${ }^{7} \mathrm{http} / / /$ rudocs.exdat.com/docs/index-128594.html

${ }^{8}$ http://referat.ru/referats/view/23656 gaiqca.htm http://www.ambebi.ge/politika/61335-saakashvili-chveni-shecdomaa-rom-yofili-qgaishnikiq-mushaobda-sistemashi-gayida-informacia-da-
} 
the element of realia, "Gaichnik ${ }^{10}$ - /GAI inspector/ we decided to use its transcription, since it proved impossible to find a French equivalent using of which would not result in the color of the given element of realia to fade.

Cultural differences influence the translator's strategy. The realia denoting political and economic structures of a particular state run the risk of misleading the reader, since the political institutions and the political-economic functions vary from country to country. For example: "L'Administration américaine" /The U.S. administration/ - in general, stands for the executive government of the USA that, unlike European states, is divided into departments. A head of each department is called a "secretary", for example : "Le secrétaire à la Défense" ("The Secretary of Defense") performs the duties of the Minister of Defense in the USA reality, so it would be a mistake to translate "Le secrétaire à la

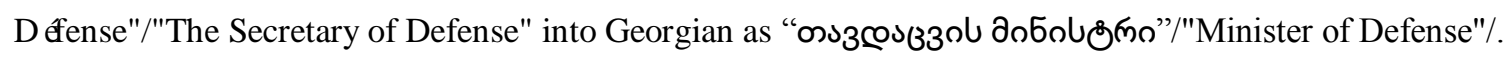

- Obama envisage Kerry comme secrétaire à la Défense, Rice comme secrétaire d'État ${ }^{11} /$ Obama considering John

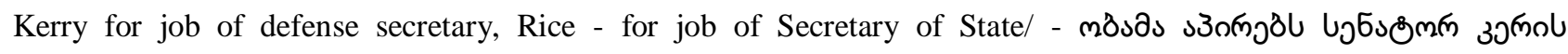

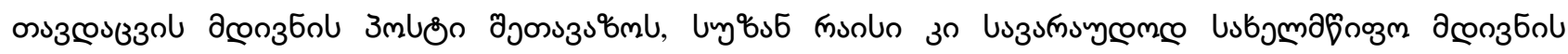

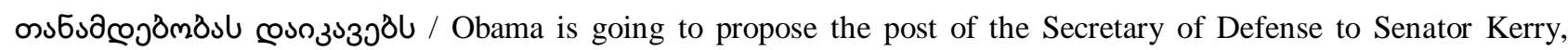
Susan Rice is likely to be appointed US Secretary of State/.

- La garde des sceaux aurait demandé d'enquêter après une fuite dans la presse-(Le Monde 27.09.2012)/The Keeper

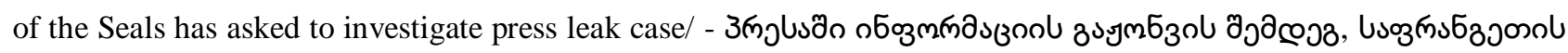

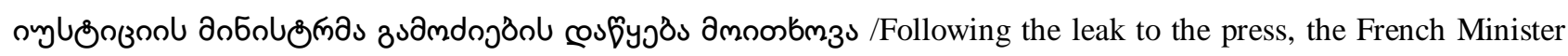
of Justice ordered the investigation of the case/.

The first title includes elements of American realia. We think it is necessary to preserve them in the translation. In this case, the explanations are not needed, because these elements of realia are well -known to the Georgian reader. Thus, the translation preserves the elements of realia "Secretary of State" and "Secretary of Defense" and we do not use "Prime Minister" and "The Minister of Defense" instead. The second title includes a French realia: "La Garde des Sceaux" ("The Keeper of the Seals") - a title used only in a few countries, including France. Consequently, in the process of translation it is necessary to use the method of generalization, in order to make the element of realia understandable for the Georgian reader. Naturally, in this case the overtones of the element of realia are lost, though the content is preserved.

Lack of knowledge and unawareness of the realia included in the source text is one of the essential difficulties a translator can face. Also it is difficult to translate the words the meanings of which might seem familiar at first glance, but their meanings have changed since the publication of the original text. However, the translator should not fall under the influence of a foreign world, and should not be looking for an element of realia in every single word. We must remember that using an element of realia the author does not always try to emphasize the essence of the element of realia and does not always intend to make the readers focus on it. Preservation of both the connotation and the overtones of a given text in the translation is as important as rendering the semantic meaning of a word. That is why the preference should always be given to the target readers and their pragmatic and aesthetic nature should be taken into consideration.

\section{REFERENCES}

[1] Barkhudarov, L. S. (1975). Yazyk i perevod: Voprosy obshchey i chastnoy teorii perevoda. Moskva: Mejdunarodnie otnoshenia.

[2] Charadeau, P. (1983). Langage et discours, Éléments de sémiolinguistique (théorie et pratique). Paris : Hachette.

[3] Charadeau, P. (2005). Les médias et l'information. L'impossible transparence du discours. Bruxelles: Editions de Boeck.

[4] Gile, D. (2005). La traduction, la comprendre, l'apprendre. Paris: Presses Universitaires de France.

[5] Hoek, L. (1981). La marque du titre. La Haye: Mouton.

[6] Komissarov, V. N. (1990). Teoria Perevoda (Lingvistickeskie aspekty). Moskva: Visshaya Shkola.

[7] Lederer, M. (2006). Le sens en traduction. Caen : Lettres modernes Minard.

[8] Nida, E. (1975). Language Structure and Translation. Stanford : Stanford University Press.

[9] Tomakhine, G. D. (1988). Realii-amerikanizmi: posobie po stranovedeniu. Moskva: Visshaya Shkola.

[10] Vereshagin, E.M., Kostomarov, V.G. (1990). Yazyk i kultura: lingvostranovedenie v prepodavanii russkogo yazika kak inostrannogo. Moskva: Russki yazyk.

[11] Vinay, J.-P., Darbenlet, J. (1958). Stylistique comparée du français et de l'anglais. Paris: Didier Erudition.

[12] Vlakhov, S., Florin S. (1986). Neperovodimoe v perevode. Moskva: Visshaya Shkola

\footnotetext{
${ }^{10}$ traffic inspector

${ }^{11}$ http://vigiinfos.canalblog.com/archives/2012/11/14/25576790.html
} 


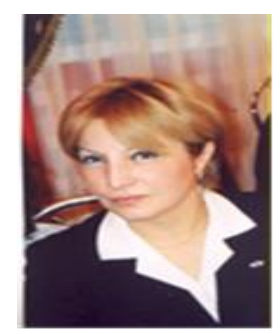

Ketevan Djachy was born in Tbilisi, Georgia on 27 August 1956. In 1973 she has obtained the Certificate of Secondary education, honored with Gold Medal, at school N 23. In 1978 she was graduated with Bachelor degree in French Language of the Roman-German faculty at M. Lomonosov University of Moscow. In 1990 has defended Doctoral Thesis and has obtained the Diploma of PHD in comparative linguistics, Iv. Javakhishvili State University of Tbilisi. In 1996 has obtained the Certificate of a Docent. In 2002 has defended Thesis of Habilitation and has obtained the Diploma of a Doctor of Sciences in Romance philology, Iv. Javakhishvili State University of Tbilisi.

She was Teaching Assistant in Ilia Chavchvadze State Institut of Foreign Languages of Tbilisi. In 1996 she has conferred the scientific-pedagogical title of the Docent. From 2002 to 2006 she was Professor FLE /LEA at the Branch of Paul Valéry State University of Montpellier III of Ilia State University of Tbilisi. Since 2006 she is Full Professor of Ilia State University of Tbilisi. Since 2003, she is member of Special research group 4509, "Sense, Text, Computer, History", in Sorbonne University (Paris IV), is mentioned on the WEB page http://www.univ-paris3.fr/publications47878.kjsp?RH=1257522045619. She had participated in 10 International Conferences. She had obtained beneficiary grants of individual mobility 6 times. In 2000, she took the 3th place in Competition among Universities' Professors, held by Embassy of France and was awarded with prize. She took part participated in Trainings (2009 course for Trainer of Information's TechnologyPassport TIC, Transfer-Georgia-Tbilisi, organized by AUF, 1999- organized by Embassy of France and Georgian Ministry of Education, 1992-"Language, Culture, Methodology", for Teachers, in "Alliance Française" in Paris, France). In 1997, she has participated in three broadcasts on the "France Culture" and two TV broadcasts on "France 2" in Paris.

Since 1994 she is Simultaneous Interpreter (French-Georgian-French, Russian-French) and has participated in International Conferences, organized by International organizations, as BSEC, PABSEC, UNESCO, TAD, NATO, Council of Europe, dedicated to political, economical, law, social issues. Author of 18 books and 70 articles:

1.The economic terminology in French and its problems of translation into Georgian, (in French), in SCOLIA, Translation of norms and norms of translation in the European area, Strasbourg, 2011, N 25, pp 187-199;

2. K. Djachy, M. Pareshishvili, The terms of translation of political newspaper articles headlines from French to Georgian, (in English) in USA \& Sino-US English Teaching, EBSCO, Ulrich; 2012, volume 10, serial number 2, February, pp. 966-973;

3. K. Djachy, N. Lomia, Characteristics of Expression of basic Emotions in Italian, Literary texts of XX century, (in English), in USA \& Sino-US English Teaching, EBSCO, Ulrich 2012, volume 10, serial number 3, March, pp. 1050 - 1060.

Prof. Djachy is Member of scientific and editorial board of International Iranian Review "Le Linguiste" and Member of International Organizations (Since 2012-OEP, CIEF, Since 2010-TIA, 2006-Group LTT of AUF). She has been Member of Doctorate Board (2010, 2009-Baku, 2006-Paris IV) at the international level and at the national level 40 times. In 2011 was invested as Chivalry an Order of Academic Palms, by Mr. Eric Fournier, Ambassador of France in Georgia, to contribution to French cult ure.

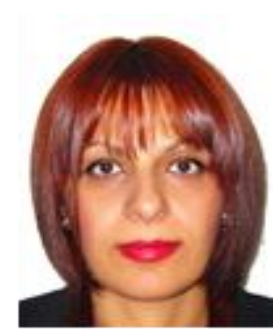

Mariam Pareshishvili was born on 9, 1978 in Tbilisi, Georgia. In 1996 she finished school N 167. In 2001 she completed a full academic course of the Tbilisi Ilia Chavchavadze State University of Language and culture (translator-Interpreter). In 2001 she was enrolled in the Department of Simultaneous Interpretation and was granted the qualification of simultaneous Interpreter. In 2013 she defended the doctoral dissertation in translations studies (the degree of doctor of philosophy in philology) in Ilia State University in Georgia.

She is French teacher in Georgian University of Patriarchate. From 2003 to 2008 she was teacher at the Department of Simultaneous Interpretation. In 2011 she has the probation in ESIT, Graduate School of Translation and Interpreting (Université de la Sorbonne Nouvelle). Since 2003 she is simultaneous interpreter (French-Georgian-French) and has participated in Conferences, organized by International organizations (NATO, Council of Europe etc). She is Author of 8 scientific publications.

1.K. Djachy, M. Pareshishvili, The terms of translation of political newspaper articles headlines from French to Georgian, (in English) in USA \& Sino-US English Teaching, EBSCO, Ulrich; 2012, volume 10, serial number 2, February, pp. 966-973;

2. Metaphor translation in newspaper articles headlines (in French), in Le Linguiste, International Journal in science of language, Teheran, Autumn N 3, 2012, pp. 31-38, ISSN 2251-970X;

3. The role of background knowledge in translation of newspaper articles headlines from French to Georgian (in French) in Le Linguiste, International Journal in science of language, Teheran, Summer N 6, 2013, pp. 65 -70, ISSN 2251-970X.

Dr. Pareshishvili is member of CIEF. Since 2010 she is member of Association of Translator and Interpreters. She had participated in International and local Conferences. 